Патика М. В., доктор сільськогосподарських наук

Національний науковий центр «Інститут землеробства НААН»

Колодяжний О. Ю., аспірант

(науковий керівник - доктор сільськогосподарських наук М. В. Патика)

Національний університет біоресурсів і природокористування України

\title{
ФОРМУВАННЯ МІКРОБНОГО КОМПЛЕКСУ ЧОРНОЗЕМУ ТИПОВОГО В АГРОЦЕНОЗ ПШЕНИЦІ ОЗИМОЇ ЗА РІЗНИХ СИСТЕМ ЗЕМЛЕРОБСТВА
}

\section{Рецензент - доктор біологічних наук I. І. Кочевський}

У процесі порівняльного аналізу формування мікробного комплексу чорнозему типового в агроченозі пшениці озимої виявлено рівень диференціації чисельності основних фізіологічних $i$ таксономічних груп мікробіому. Показано особливості формування структури, якісного складу та різноманіття бактеріального комплексу за різних систем землеробства й обробітку трунту. Встановлено, шзо систематичне внесення органічних добрив дозволяс оптимізувати мікробіологічні процеси та сприяє збільшенню видового різноманіття з рівномірним розподілом із домінуючих форм мікроорганізмів.

Ключові слова: пшеничя озима, мікробний комплекс, структура мікробоченозу, біорізноманіття, чорнозем типовий, система землеробства, обробіток трунту.

Постановка проблеми. Мікробний ценоз - це один із найскладніших, найрізноманітніших i найпоширеніших типів просторово-функціональної організації живих угруповань педосфери. Мікроорганізми є основним джерелом генетичного різноманіття, що має широку видову й функціональну варіабельність. Завдяки складному видовому різноманіттю з відповідною ферментативною активністю, мікробіота відіграє виключно важливу роль у трансформації органічної матерії, процесах грунтоутворення та формуванні родючості грунтів $[8,11]$.

Формування певного мікробного комплексу грунту, його структури та складу з відповідною функціональною активністю в значній мірі залежить від його типу, агрегатного складу, обумовленого аграрним використанням та особливостями сільськогосподарських культур [3].

Структура мікробних ценозів - невід'ємна складова детальної характеристики грунтів, включаючи процеси та фактори, що прямо чи опосередковано впливають на їх особливості.

Аналіз останніх досліджень і публікацій, у яких започатковано розв'язання проблеми. Дослідженнями вітчизняних та зарубіжних вче- них встановлено, що мікробіота є невід'ємним гомеостатичним компонентом грунту, котрий здійснює й визначає у ній важливі функції трансформації сполук та енергіiі. Мікроорганізми - невід'ємна ланка кругообігу всіх біогенних елементів, що здійснює як продукційні, так і деструкційні процеси [12].

Особливості взаємодії мікроорганізмів між собою і рослинами мають різноманітні функціональні характеристики, що формують стійкі мікробні комплекси агроекосистем. Понад $95 \%$ прокариотних мікроорганізмів грунтів потребують комплексної оцінки трофічних зв'язків під впливом різних екологічних умов. Одним із важливих завдань грунтової мікробіології є об' єктивна комплексна оцінка складних зв'язків і розкриття механізмів взаємодії між мікробними ценозами та середовищем їх існування [7].

Збереження й підтримання гомеостазу біорізноманіття, оптимізація структури та текстури мікробного комплексу $є$ важливим завданням у процесі розкриття механізмів взаємодії у системі «Грунт - мікроорганізми - рослина» й визначальним фактором науково обгрунтованого управління грунтово-мікробними процесами у формуванні стійких високопродуктивних агроекосистем [6].

Мета і завдання досліджень. Метою досліджень було вивчити особливості формування мікробного комплексу чорнозему типового в агроценозі пшениці озимої за різних систем землеробства.

Завдання досліджень - провести порівняльну характеристику чисельності основних фізіологгічних i таксономічних груп мікроорганізмів, аналіз якісного складу, структури та різноманіття мікробного комплексу чорнозему типового, що формується в онтогенезі пшениці озимої за різних систем землеробства.

Матеріали та методика досліджень. Дослідження мікрофлори чорнозему типового проводилося на базі стаціонарного польового досліду 


\section{СІЛЬСЬКЕ ГОСПОДАРСТВО. РОСЛИННИЦТВО}

кафедри землеробства та гербології НУБіП України. Територія досліджуваного поля знаходиться в правобережній частині Лісостепу України. Рельєф місцевості - рівнинний. Грунт ділянки - чорнозем типовий, малогумусний; за гранулометричним складом - грубопилуватий середній суглинок.

Особливістю досліджуваних систем землеробства $є$ варіанти ресурсного забезпечення для відтворення продуктивного потенціалу агроландшафту. За промислової системи (ПС) землеробства (контроль) на гектар ріллі в сівозміні вноситься 12 т органічних і 300 кг діючої речовини мінеральних добрив $\left(\mathrm{N}_{92} \mathrm{P}_{100} \mathrm{~K}_{108}\right)$ із відповідним хімічним захистом посівів. У екологічній моделі землеробства (ЕС) пріоритетним є застосування органічних добрив у кількості 24 т/га (12 т/га гною, 6 т/га нетоварної, побічної частини урожаю сільськогосподарських культур, 6 т/га сидеральної маси пожнивних посівів). Баланс елементів живлення компенсується мінеральними добривами $\mathrm{N}_{46} \mathrm{P}_{49} \mathrm{~K}_{35}$.

Основою біологічної моделі системи землеробства (БС) є внесення 24 т/га ріллі органічних добрив у сівозміні без застосування промислових агрохімікатів із використанням біологічних засобів захисту посівів [10].

На фоні варіантів ресурсного забезпечення досліджувалися системи диференційованого (ДО) та поверхневого (ПО) основного обробітків грунту. Відбір та аналіз грунтових зразків проводились у фазу цвітіння й воскової стиглості пшениці озимої з верхнього (0-20 см) орного кореневмісного шару грунту [2].

Чисельність мікроорганізмів основних фізіологічних і таксономічних груп визначалася методом посіву грунтових суспензій на відповідні елективні поживні середовища $[2,9]$.

Вологість грунту визначалась термостатноваговим методом. Якісний склад мікробного комплексу вивчався на основі представленості морфолого-культуральних типів.

Для визначення ступеня домінування використовувався показник насиченості виду, \% = (ax100)/А, де: a - кількість колоній певного морфотипу; А - загальна кількість колоній $[1,4]$. Для екологічної оцінки біорізноманіття мікроорганізмів у грунті розраховувались індекси Шеннона (H) та Сімпсона (C) [5]. Статистична обробка отриманих результатів проводилась із визначенням середніх квадратичних відхилень та довірчих інтервалів у MS Excel.

Результати досліджень. За результатами досліджень встановлено значні зміни у формуванні чисельності та структури основних фізіологіч- них і таксономічних груп мікроорганізмів в онтогенезі пшениці озимої під впливом систем землеробства та обробітку грунту.

Так, по відношенню до азоту та його форм у фазу цвітіння пшениці озимої (рис. 1) чисельність амоніфікувальних бактерій за екологічної та біологічної систем землеробства у 3-3,2 рази була вищою, ніж за промислової системи. Чисельність мікроорганізмів, що використовують мінеральні форми азоту, за поверхневого обробітку грунту коливалася від 18,37 до 19,91 млн КУО/г грунту залежно від систем землеробства. За диференційованого обробітку їх чисельність суттєво відрізнялась і становила: за промислової системи - 7,59, за екологічної - 10,66 , за біологічної - 24,41 млн.

Збільшення чисельності та співвідношення амоніфікувальних мікроорганізмів та іммобілізаторів мінерального азоту вказує на прискорення процесів трансформації органічної речовини, коли мінеральний азот включається в процеси метаболізму мікроорганізмів, особливо за екологічної та біологічної систем землеробства, створючи умови конкуренції рослин і мікроорганізмів за мінеральний азот.

Як наслідок, кількість олігонітрофільних бактерій за промислової системи землеробства становила 6,79 за диференційованого обробітку та 9,73 - поверхневого, а за біологічної системи збільшувалась до 19,03 та 18,22 млн відповідно.

Чисельність целюлозоруйнівних мікроорганізмів, що активно функціонують у мікробоценозі на початкових етапах трансформації органічної речовини, суттєво відрізнялася в досліджуваних системах землеробства. За промислової системи їх чисельність становила 462,45 тис. КУО/г за диференційованого обробітку та 505,21 - поверхневому; за біологічної - 561,10 і 788,67 відповідно обробітку грунту й значно збільшувалась за екологічної, відповідно, 970,17 та 825,40 тис. Збільшення чисельності спороутворюючих бактерій у 2,5 разу відбувалося за екологічної й майже в 7 разів за біологічної систем землеробства 3 диференційованим обробітком, порівняно 3 промисловою $(0,87$ та 2,67 млн за диференційованого та поверхневого обробітку відповідно), що свідчить про активну участь вищезазначених груп у процесах трансформації органічних решток.

Підвищення чисельності стрептоміцетів до 3,05-3,92 млн спостерігалось за екологічної та біологічної систем землеробства. Чисельність мікроміцетів чорнозему типового збільшувалась у варіантах із пріоритетним застосуванням органічних добрив i становила 49,86-60,35 тис. КУО/г грунту. 


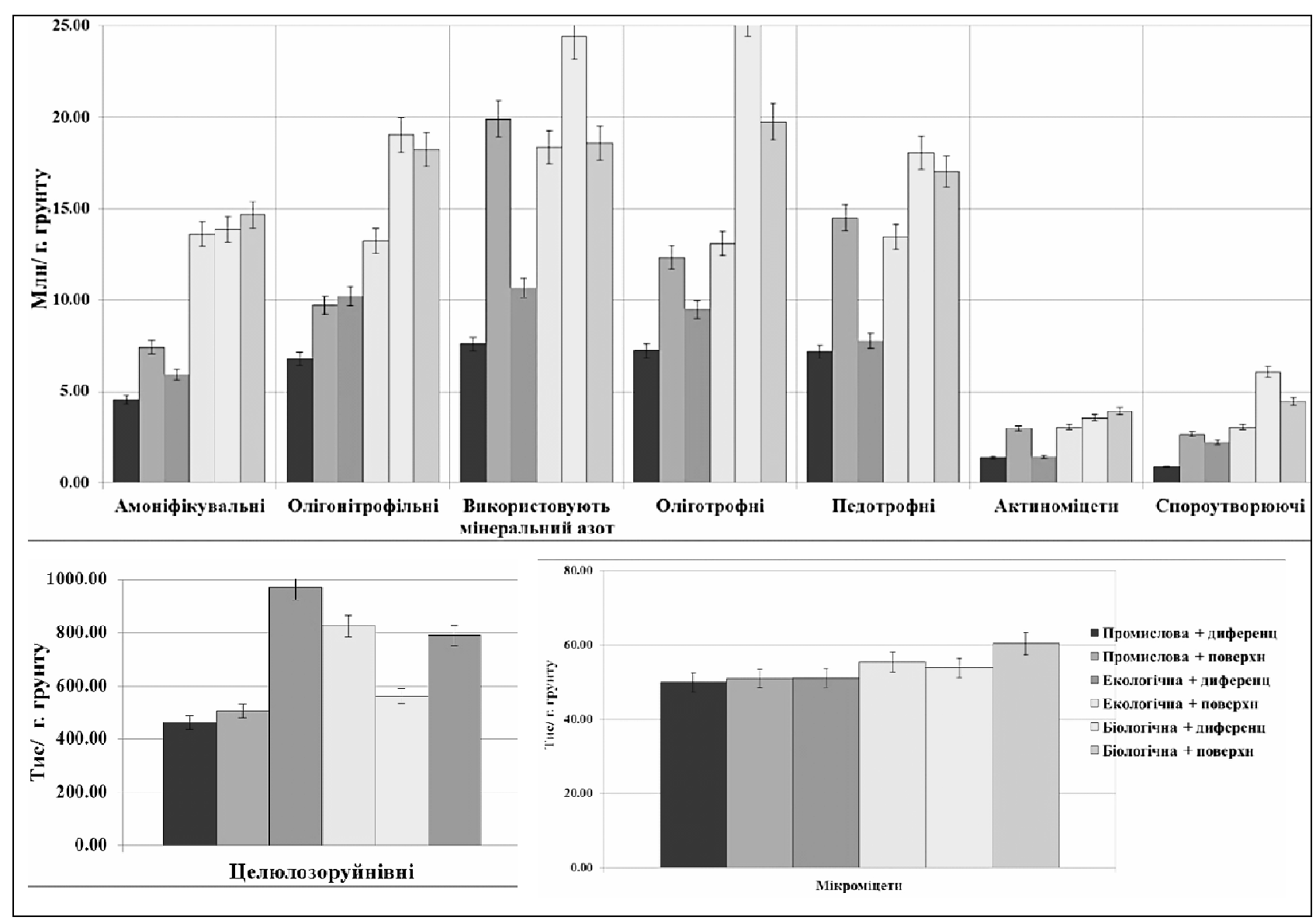

\section{Рис. 1. Чисельність основних фізіологічних груп мікробного комплексу чорнозему типового} у фазу цвітіння пшениці озимої

На фоні значної різниці чисельності основних фізіологічних груп мікроорганізмів для встановлення функціональної різноспрямованості мікробіологічних процесів важливе значення має якісний склад і структура розподілу домінуючих форм грунтової мікрофлори у варіантах досліду. У фазу цвітіння пшениці озимої загалом було описано 141 морфотип (рис. 2). Серед них домінуючих - 13, субдомінуючих - 23, що часто трапляються - 89 і випадкових - 16 штук. Значний вплив на структуру розподілу різних груп виявлених морфотипів мали системи землеробства та обробітку грунту. Так, за промислової системи землеробства 3 диференційованим обробітком грунту структура бактеріального комплексу включала 4 домінуючих, 3 субдомінуючих і 6 видів, що часто трапляються. Відбувалось удвічі збільшення видів, що часто трапляються, за поверхневого обробітку, спостерігалась активізація та включення в структуру мікробоценозу випадкових видів.

За екологічної та біологічної систем землеробства кількість домінуючих морфотипів у структурі бактеріального комплексу зменшилась до 1 , але значно збільшилася кількість видів, що часто трапляються в ценозі (до 80 та $54 \%$ відповідно), що характеризує збільшення різноманіття мікробних ценозів. За біологічної системи землеробства у структурі мікробного комплексу спостерігалась активізація випадкових форм, частка яких склала $23 \%$ за диференційованого обробітку та $26 \%$ - за поверхневого від загального числа морфотипів.

У кінці вегетації пшениці озимої спостерігалося вирівнювання структури мікробного ценозу за рахунок перерозподілу чисельності основних фізіологічних груп мікроорганізмів за варіантами досліду (рис. 3). Порівняно з фазою цвітіння, чисельність амоніфікувальних мікроорганізмів за екологічної системи землеробства дещо збільшувалась і становила 15,31 та 16,30 млн залежно від обробітку грунту. За біологічної системи їх чисельність суттєво не змінювалася й становила, відповідно, 13,91 та 12,08 млн. Відбувалося зростання чисельності амоніфікаторів за промислової системи землеробства до 12,80 за диференційованого обробітку та 11,93 млн - поверхневого. 


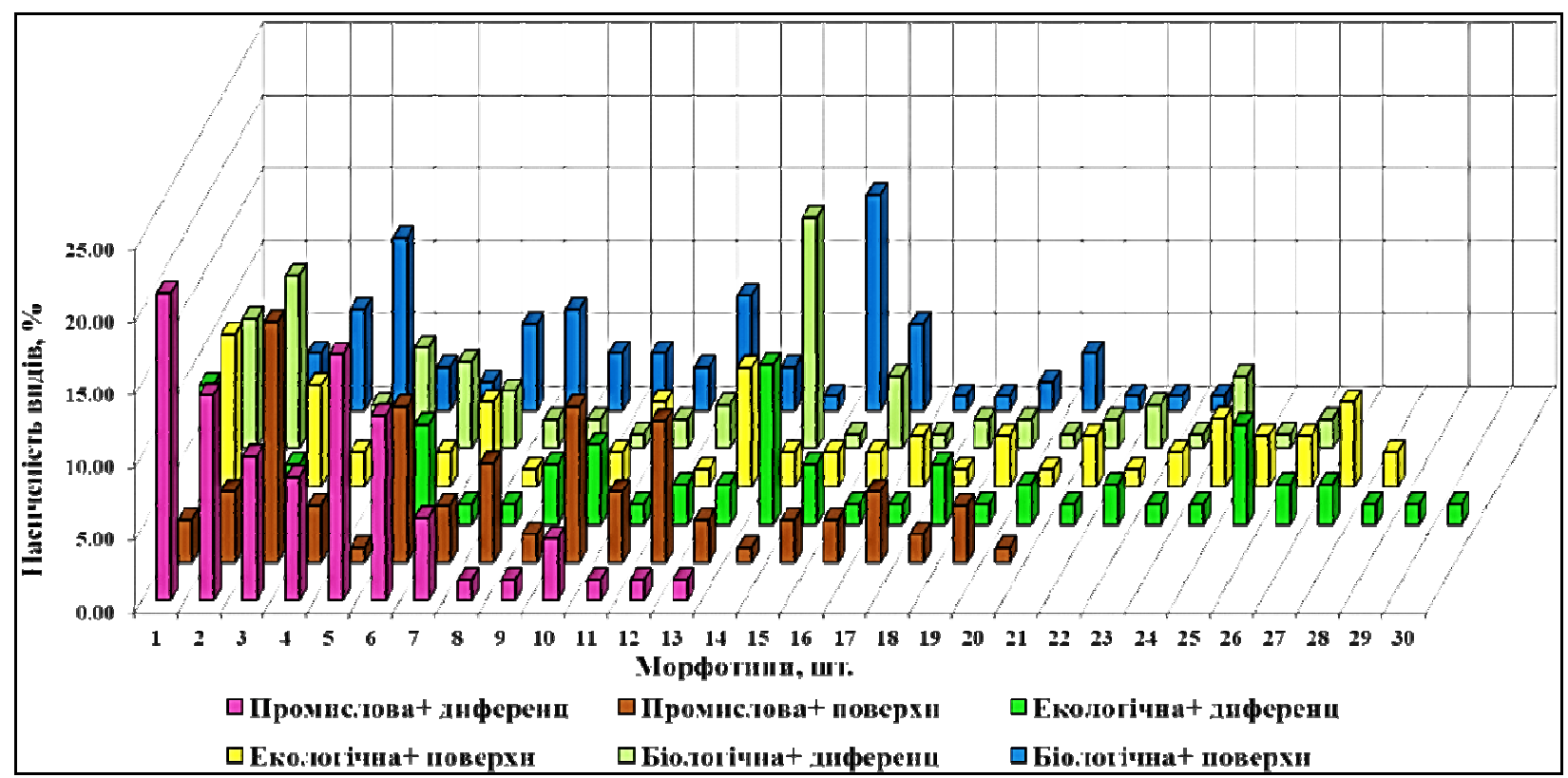

Рис. 2. Вплив систем землеробства та обробітку грунту на якісний склад прокаріот чорнозему типового (фаза цвітіння пшениці озимої)

Чисельність мікроорганізмів, що використовують мінеральний азот, збільшувалась за промислової системи 3 диференційованим обробітком грунту до 11,09 і 16,04 - 3 поверхневим і знижувалась до 11,91 за екологічної системи з поверхневим обробітком та за біологічної системи - 15,72 й 6,97 млн відповідно до обробітку грунту.

Вирівнювання кількості олігонітрофільної мікрофлори 3 варіантами досліду відбувалося за рахунок їх збільшення у промисловій системі землеробства $(10,36$ і 12,01$)$ та зниження за біологічної (12,09 і 8,01 млн відповідно до обробітку грунту). Слід зазначити зростання чисельності оліготрофів за промислової системи землеробства 3 диференційованим обробітком до 12,06 і зниження з 9,48 (у фазу цвітіння пшениці озимої) до 7,58 - за екологічної системи і з 25,7 до 7,1 млн КУО/г грунту за біологічної відповідно, що свідчить про доступність легкозасвоюваних речовин, які накопичуються в процесі трансформації органічних решток рослин. Це сприяє покращанню трофічних зв' язків у структурі мікробного комплексу грунту та зниженню чисельності педотрофів у даних варіантах.

Суттєвих змін у чисельності актиноміцетів не спостерігалось, їх кількість становила 2,22-4,08 мільйона. Відмічалося зростання чисельності спороутворюючих мікроорганізмів у цю фазу онтогенезу на всіх варіантах досліду до 4,136,46 мільйона.

Порівняно з фазою цвітіння, у кінці вегетації спостерігалося зниження й перерозподіл за варіантами чисельності целюлозоруйнівних мікроорганізмів. Негативними факторами були аномально високі температури повітря й недостатня зволоженість у даний період. Так, за промислової системи землеробства їх чисельність знизилася до 48,09 і 106,42 тис. за диференційованого та поверхневого обробітків, за екологічного - до 71,30 та 44,66 , а за біологічної - до 41,57 та 100,08 тис відповідно. Чисельність мікроміцетів чорнозему типового суттєво не змінилася, порівнюючи з фазою цвітіння пшениці озимої, й становила 51,04-60,42 тис. КУО/г грунту.

У цю фазу відбувалося накопичення органічної речовини грунту за рахунок надземної та підземної біомаси рослин. Цьому сприяла спрямованість мікробіологічних процесів і спостерігалося значне збільшення чисельності виявлених морфотипів (рис. 4). Кількість виявлених морфотипів - 216 штук. Домінуючих серед них було 3 шт., субдомінуючих - 23 шт., випадкових 40 шт. й тих, що часто трапляються, - 150 шт.

За поверхневого обробітку грунту у структурі мікробного комплексу домінуючих морфотипів виявлено не було. За диференційованого обробітку їх частка становила: $3,1 \%$ за промислової, $2,6 \%$ - за екологічної та 2,5 \% - біологічної. Основна частка мікроорганізмів, що часто трапляються, за промислової системи склала 56$66 \%$, екологічної - 63-66 \%, біологічної - 72$89 \%$ відповідно систем обробітку грунту. 


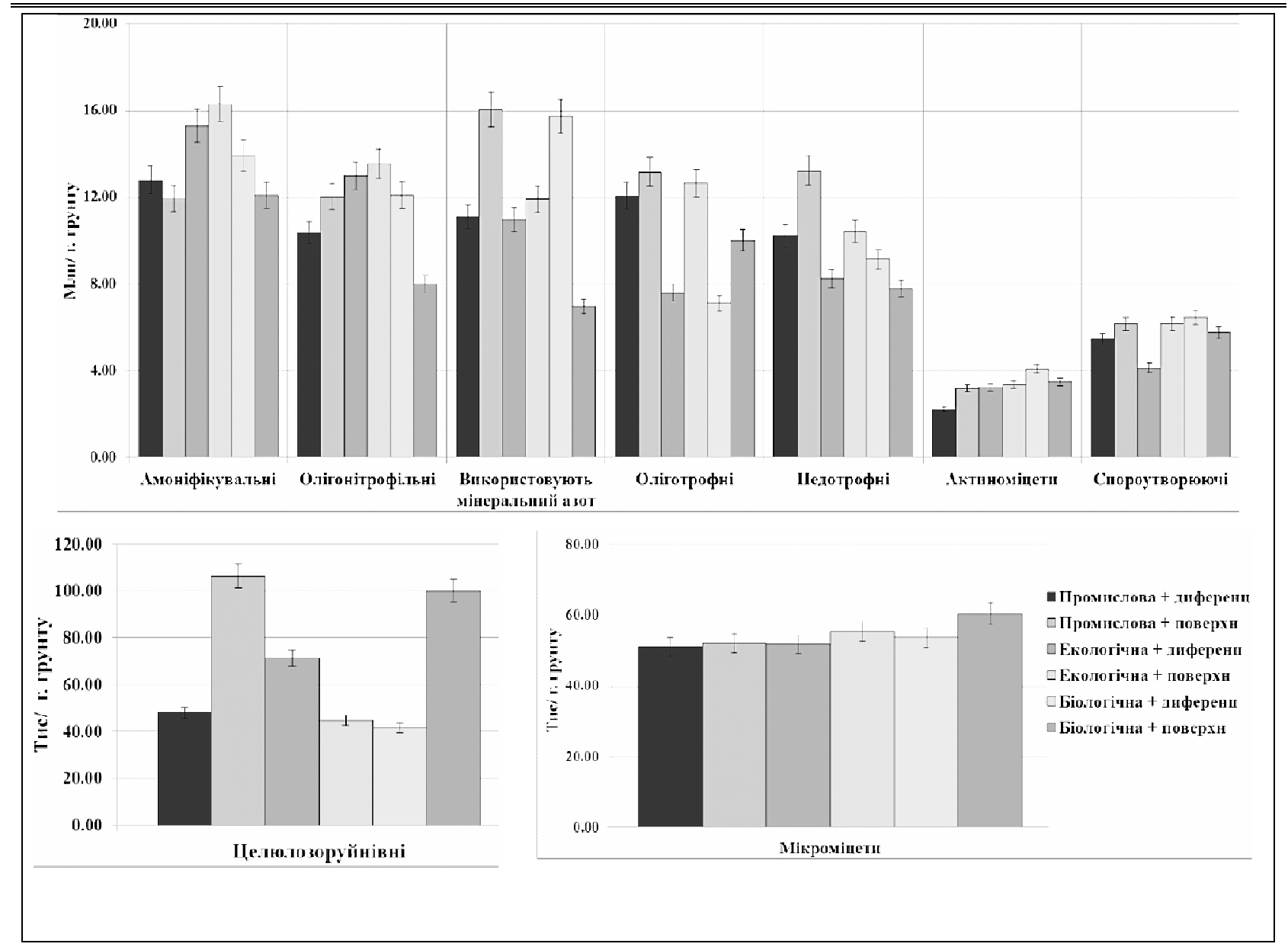

Рис. 3. Чисельність основних фізіологічних груп мікробного комплексу чорнозему типового у фазу воскової стиглості пшениці озимої

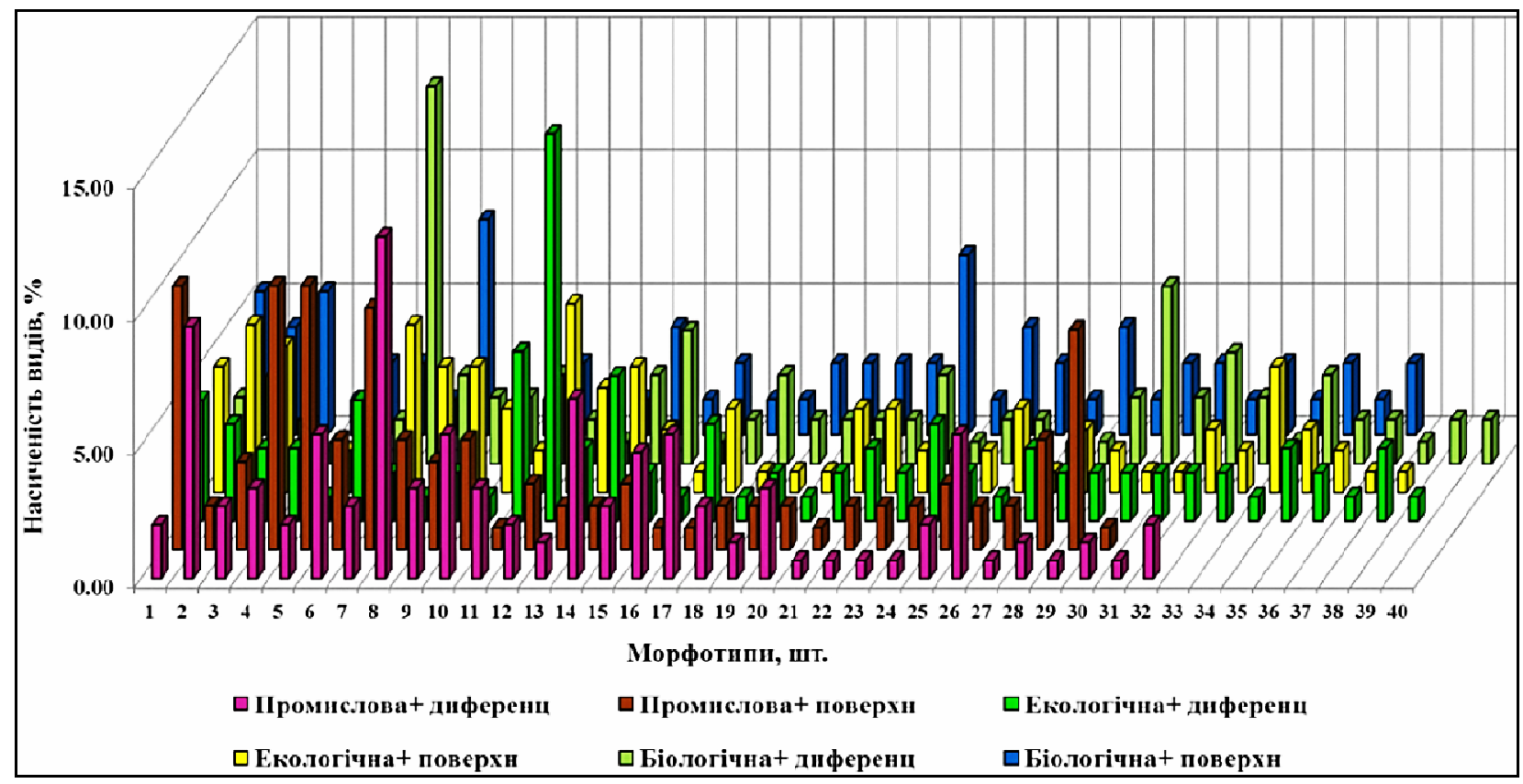

Рис. 4. Вплив систем землеробства та обробітку трунту на якісний склад прокаріот чорнозему типового (фаза воскової стиглості пшениці озимої) 


\section{СІЛЬСЬКЕ ГОСПОДАРСТВО. РОСЛИННИЦТВО}

Типологія розподілу виявлених домінуючих форм суттєво відрізнялася за системами землеробства та обробітку грунту (рис. 5). Морфотипи 1, 2, 4 були специфічними лише для промислової системи землеробства 3 диференційованим обробітком грунту. Морфотипи 3 і 5 виявлялися в промисловій та екологічній системах землеробства, 6-й був специфічним лише для промислової системи землеробства з поверхневим обробітком грунту. За біологічної системи землеробства сформувалася специфічна домінуюча мікрофлора (7-9-й морфотипи).

Серед виявлених домінантів траплялися види, що мали високу антагоністичну активність, тому $\epsilon$ перспективними для наступних досліджень i використання в біотехнології. Значення та функціональні властивості домінуючих представників мікробного комплексу мають також важливе значення безпосередньо по взаємовідношенню 3 рослинами пшениці озимої.

Порівняльна оцінка екологічних індексів формування мікробіоти чорнозему типового показала значний зв'язок між показниками біорізноманіття Шеннона та домінування Сімпсона у різні фази онтогенезу пшениці озимої (див. табл.).

Встановлено, що збільшення біорізноманіття та популяції бактеріальної мікрофлори у фазу цвітіння пшениці відбувається наступним чином: $\Pi \mathrm{C}+Д \mathrm{O} \rightarrow \Pi \mathrm{C}+\Pi \mathrm{\Pi} \rightarrow$ БС $+\Pi \mathrm{\Pi} \rightarrow \mathrm{БC}+$ ДО $\rightarrow \mathrm{EC}+$ ПО $\rightarrow \mathrm{EC}+$ ДО. За промислової системи землеробства індекс різноманіття бактеріальної мікрофлори був на низькому рівні й не перевищував 1. Індекс домінування Сімпсона за промислової системи землеробства свідчить про формування однорідного мікробного комплексу чорнозему типового з високим ступенем домінування певних морфотипів бактеріальної мікрофлори.

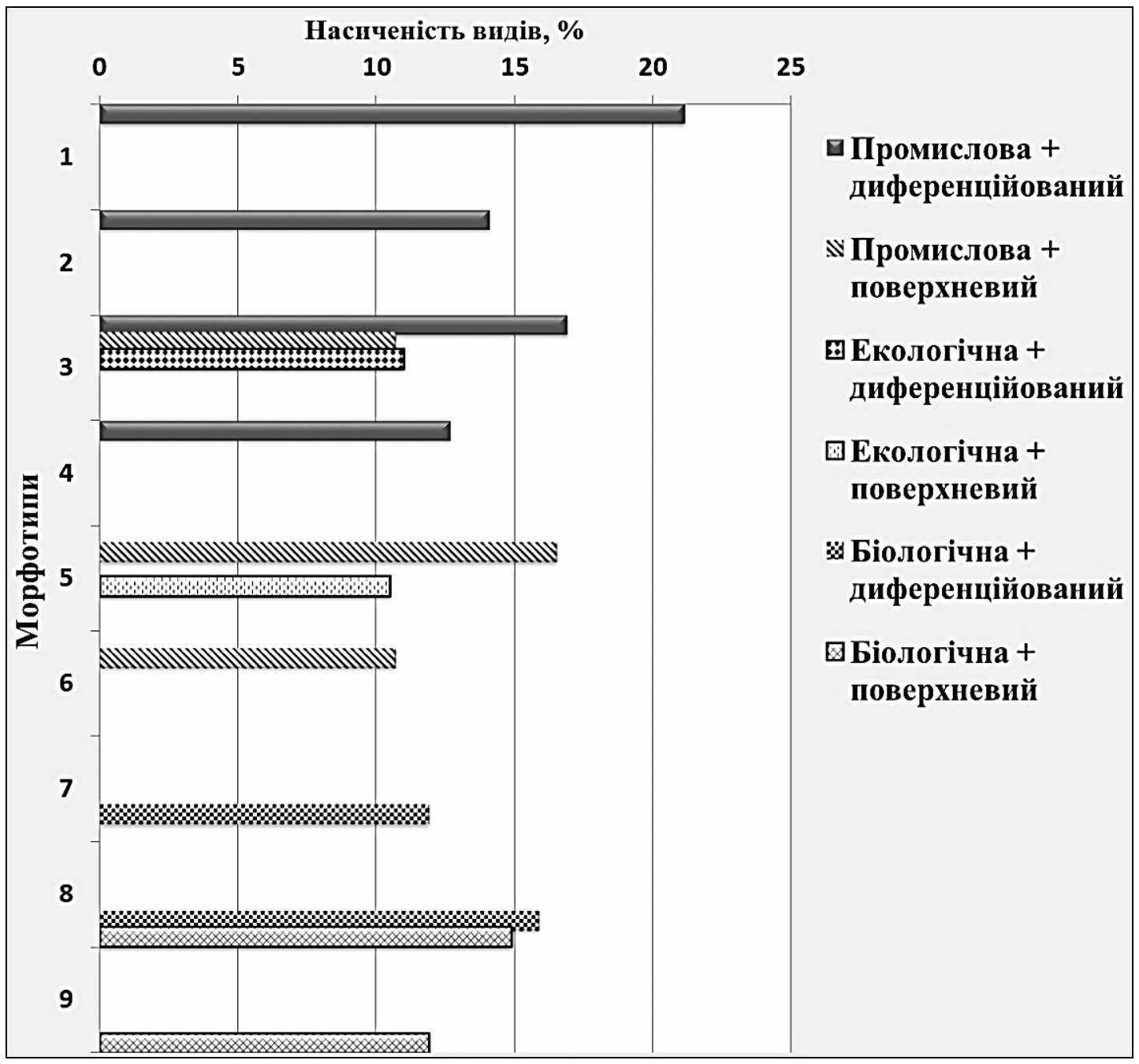

Рис. 5. Розподіл домінуючих морфотипів бактеріальної мікрофлори чорнозему типового залежнн від систем землеробства та обробітку трунту 
СІЛЬСЬКЕ ГОСПОДАРСТВО. РОСЛИННИЦТВО

\section{Екологічні індекси біорізноманіття та домінування бактеріального комплексу чорнозему типового в агроценозі пшениці озимої}

\begin{tabular}{|c|c|c|c|c|c|}
\hline \multirow{2}{*}{$\begin{array}{c}\text { Системи } \\
\text { землеробства }\end{array}$} & \multirow{2}{*}{ Обробіток грунту } & \multicolumn{3}{|c|}{ Фаза цвітіння } & \multicolumn{2}{|c|}{ Фаза воскової стиглості } \\
\cline { 3 - 6 } & & \multicolumn{4}{|c|}{ індекси } \\
\cline { 3 - 6 } & & Шеннона & Сімпсона & Шеннона & Сімпсона \\
\hline \multirow{2}{*}{ Промислова } & диференційований & 0,96 & 0,13 & 1,37 & 0,05 \\
\cline { 2 - 6 } & поверхневий & 1,19 & 0,08 & 1,34 & 0,06 \\
\hline \multirow{2}{*}{ Екологічна } & диференційований & 1,38 & 0,05 & 1,47 & 0,05 \\
\cline { 2 - 6 } & поверхневий & 1,37 & 0,05 & 1,48 & 0,05 \\
\hline \multirow{2}{*}{ Біологічна } & диференційований & 1,27 & 0,07 & 1,49 & 0,04 \\
\cline { 2 - 6 } & поверхневий & 1,24 & 0,07 & 1,50 & 0,04 \\
\hline
\end{tabular}

Зростання індексу біорізноманіття у кінці вегетації пшениці до 1,49 та 1,50 за біологічної системи землеробства 3 диференційованим та поверхневим обробітком обумовлено накопиченням у грунті поживних для мікроорганізмів легкозасвоюваних речовин. Застосування промислової системи землеробства призводило до зниження різноманіття (1,34 й 1,37 відповідно). Зниження індексу домінування Сімпсона свідчить про формування стабільних гомеостатичних систем грунтових мікроорганізмів, що сприяє рівномірному розподілу видів і розширенню складності й трофічних зв'язків мікробного ценозу.

Висновки: 1. Застосування екологічної та біологічної систем землеробства дає можливість оптимізувати мікробіологічні процеси в період активної вегетації пшениці озимої, що сприяє створенню умов для збільшення втричі чисельності амоніфікувальних бактерій, в 1,8-2,5 олігонітрофільних, в 2,4-3 мікроорганізмів, що використовують мінеральні форми азоту, в 2,5-6,5 спороутворюючих і в 1,5 - рази целюлозоруйнівних мікроорганізмів та зменшенню у фазу стиглості пшениці озимої чисельності мікроорганізмів, що використовують мінеральні форми азоту, в 1,5-2,3, оліготрофів - у 1,5 і педотрофів -

\section{БІБЛІОГРАФІЯ}

1. Емщев В. T. Микробиология: учебник для вузов / В. Т. Емцев, Е. Н. Мишустин. - 5-е изд., перераб. и доп. - М. : Дрофа, 2005. - С. 205-206.

2. Звягиниев Д. Г. Методы почвенной микробиологии и биохимии / Под ред. Д. Г. Звягинцева - М. : Из-во МГУ, 1991. - 330 с.

3. Иутинская Г. А. Почвенная микробиология / Г. А. Иутинская. - К. : Аристей, 2006. - 284 с.

4. Лабутова Н. М. Методы изучения почвообитающих микроорганизмов : Учебное пособие / в $1,5-1,7$ разів.

2. Формування різноманіття мікробного комплексу, збільшення видового багатства мікроорганізмів із незначною кількістю домінуючих форм і більш рівномірним їх розподілом та високим ступенем різнонаправленості мікробіологічних процесів обумовлено систематичним внесенням органічних добрив для відтворення ресурсного потенціалу й науково обгрунтованими системами обробітку грунту.

3. Систематичне внесення значної кількості мінеральних добрив призводить до порушення трофічних зв'язків у мікробному комплексі, структури чисельності фізіологічних груп мікроорганізмів, зниження біорізноманіття та формування однорідного мікробіому чорнозему типового 3 високим ступенем домінування певних видів бактеріальної мікрофлори.

4. Науково обгрунтоване використання принципів формування мікробної складової грунту, збереження гомеостазу біорізноманіття, оптимізація структури мікробного комплексу є основою для технологій різного рівня в напрямі удосконалення адаптивних систем землеробства за створення стійких високопродуктивних агроекосистем та управління грунтовою родючістю в цілому.

Н. М. Лабутова. - СПб.ГУ, 2008. - С. 13-16.

5. Одум Ю. Основы экологии / Под ред. Н. П. Наумова. - М. : Мир, 1975. - 733 с.

6. Патика М. В. Формування біорізноманіття та філотипової структури еубактеріального комплексу чорнозему типового при вирощуванні пшениці озимої / М. В. Патика, С. П. Танчик, О. Ю. Колодяжний [та ін.] // Доповіді НАН України. - 2012. - № 11. - С. 163-171.

7. Патыка Н. В. Агробиология микрооргани- 
змов: разнообразие, структурная организация и функциональные особенности / Н. В. Патыка, В. Ф. Патыка // Імунологія та алергологія: наука і практика. - 2014. - Додаток № 1. - С. 77-78.

8. Патыка H. В. Прокариотические микроорганизмы почвы: структура и функциональное разнообразие / Н. В. Патыка, Ю. В. Круглов, Е. В. Шеин // Тезисы докладов ХІІІ Съезда общества микробиологов Украины им. С. Н. Виноградского. - Ялта, 2013. - C. 46.

9. Практикум по микробиологии: Учеб. пособие для студентов высшых учеб. заведений / А. И. Нетрусов, М. А. Егорова, Л. М. Захарчук [и др]. - М. : Издательский центр «Академия»,
2005. - $608 \mathrm{c}$.

10. Танчик С.П. Екологічна система землеробства в Лісостепу України / С. П. Танчик, О. А. Демідов, Ю. П. Манько [та ін.] // Методичні рекомендації для впровадження у виробництво. - К. : НУБіП України, 2011. - 39 с.

11. Microbial diversity and soil functions / P. Nannipieri, J. Ascher, M. T. Ceccherini [et al] // European Journal of Soil Science. - 2003. - Vol. 54. P. 655-670.

12. Microbial Diversity in Soils / B. Giri, P. Huong Giang, R. Kumari [et al] // Microorganisms in Soils: Roles in Genesis and Functions. - 2005. - P. 19-49. 